\title{
Ecologically sustainable but unjust? Negotiating equity and authority in common-pool marine resource management
}

\author{
Sarah C. Klain $^{1}$, Rachelle Beveridge ${ }^{2}$ and Nathan J. Bennett ${ }^{3,4}$
}

\begin{abstract}
Under appropriate conditions, community-based fisheries management can support sound resource stewardship, with positive social and environmental outcomes. Evaluating indigenous peoples' involvement in commercial sea cucumber and geoduck fisheries on the central coast of British Columbia, Canada, we found that the current social-ecological system configuration is relatively ecologically sustainable according to stock assessments. However, the current system also results in perceived inequities in decisionmaking processes, harvesting allocations, and socioeconomic benefits. As a result, local coastal resource managers envision a transformation of sea cucumber and geoduck fisheries governance and management institutions. We assessed the potential robustness of the proposed institutions using Elinor Ostrom's common-pool resource design principles. Grounded in the region's legal, political, and historical context, our analysis suggests that greater local involvement in these invertebrate fisheries and their management could provide more benefits to local communities than the status quo while maintaining an ecologically sustainable resource. Our research highlights the importance of explicitly addressing historical context and equity considerations in social-ecological system analyses and when renegotiating the institutions governing common-pool resources.
\end{abstract}

Key Words: benthic fisheries; common-pool resources; CPR design principles; environmental governance; indigenous or aboriginal peoples; resource management; small-scale fisheries; social-ecological system framework

\section{INTRODUCTION}

Historically, many natural resources have been managed by centralized government institutions and industry (Cox et al. 2010, Ostrom and Cox 2010). Top-down management regimes, Hardin (1968) argues, are necessary to avoid so-called "tragedies of the commons," wherein local resource users overharvest the resource to maximize their own short-term benefit. Yet, in an age of unprecedented ecological decline, scholars and natural resource managers increasingly recognize the potential for local communities to manage common-pool resources (CPRs) sustainably (Ostrom 1999, Agrawal 2003, Cox et al. 2010, Basurto and Nenadovic 2012). Resource-based communities can play a fundamental role in retaining the knowledge and practices essential to promoting social-ecological resilience (Berkes 2012b, Cinner et al. 2012b). In many contexts, adaptive (co-)management regimes that recognize and support local institutions may be preferable to and more effective than hierarchical command-andcontrol systems (Plummer and Armitage 2007, Levin and Lubchenco 2008, Mahon et al. 2008, Armitage et al. 2009, Berkes 2009, Plummer 2009, Cox et al. 2010, Ostrom 2010, Plummer et al. 2012).

Globally, the recognition of local management benefits has led many governments to decentralize natural resource management to local groups and co-management processes (Cox et al. 2010, Ostrom and Cox 2010). However, community-based resource management is not a panacea, and not all local institutions are successful from process or outcome perspectives. Scholars of natural resource governance and resilience have asked: What institutional design principles tend to characterize the sustained and productive use of CPRs (Ostrom 1990, 1999, Agrawal 2003, Cox et al. 2010, Basurto and Nenadovic 2012)? Numerous case studies and comparative analyses have confirmed that there are certain design principles that can increase the likelihood that institutions will be robust and support sustainable socialecological systems (Table 1).
On the West coast of Canada, fisheries management remains a largely top-down process (Kearney et al. 2007, Berkes 2012a, Cinner et al. 2012b) that is increasingly understaffed and underfunded (Hutchings and Post 2013). Regarding the use and management of local resources, federal authorities in Canada are obligated by law to consult with indigenous peoples, who are legally referred to as Aboriginal, but are commonly self-identified as First Nations, Inuit, or Metis. However, the protocols and processes by which to conduct consultations are still emerging and evolving. Many First Nations are demanding to be recognized as natural resource stewards, included in decision-making and governance processes as equal partners, and allocated a fair share of harvesting rights and benefits. In this changing governance landscape, many First Nations are challenging federal management authority using rights-based arguments. The aboriginal right to fish commercially is not broadly recognized, but has been recognized in individual court decisions. In 2014, the Supreme Court of Canada refused to hear an appeal to the Ahousaht Indian Band and Nation v. Canada (Attorney General) 2009 (B.C.S.C. 1494) decision upholding the Ahousaht Nation commercial fishing rights (Ha-Shilth-Sa 2014). In the recent Tsilhqot'in Nation v. British Columbia 2014 (S.C.C. 44), the Supreme Court granted Aboriginal Title to a tract of land for the first time. However, the full implications of this decision are still uncertain, particularly as it pertains to marine resources.

Here, we focus on a case study of commercial sea cucumber (Parastichopus californicus) and geoduck (Panopea abrupta) fisheries management on the central coast of British Columbia (BC), Canada, to shed light on problems of equity in the current governance process and social outcomes of these fisheries. We focus on these benthic invertebrates because of their spatially constrained adult life stages and the related ease in clearly defining management boundaries. Furthermore, both geoduck and sea cucumber are lucrative fisheries that currently provide few opportunities and little income to First Nation communities; only 
Table 1. Overview of common-pool resource (CPR) design principles. Source: Cox et al. (2010).

\begin{tabular}{|c|c|}
\hline Design principle & Description \\
\hline 1A. Clearly defined user boundaries & $\begin{array}{l}\text { Individuals or households who have rights to withdraw resource units from the CPR are } \\
\text { clearly defined }\end{array}$ \\
\hline 1B. Clearly defined resource boundaries & The physical boundaries of the CPR are well defined \\
\hline $\begin{array}{l}\text { 2A. Congruence between appropriation and provision } \\
\text { rules and local conditions }\end{array}$ & $\begin{array}{l}\text { Appropriation rules restricting time, place, technology, and/or quantity of resource units } \\
\text { are related to local social and ecological conditions }\end{array}$ \\
\hline 2B. Inputs proportional to benefits & $\begin{array}{l}\text { The benefits obtained by users from a CPR are proportional to the amount of inputs } \\
\text { required in the form of labor, material, or money, as determined by provision rules }\end{array}$ \\
\hline 3. Collective-choice arrangements & $\begin{array}{l}\text { Most individuals affected by the operational rules can participate in modifying the } \\
\text { operational rules }\end{array}$ \\
\hline 4A. Monitoring users & Monitors are present and actively audit CPR conditions and appropriator behavior \\
\hline 4B. Monitoring resource & Condition of the resource is monitored by people who are accountable to the users \\
\hline 5. Graduated sanctions & $\begin{array}{l}\text { Appropriators who violate operational rules are likely to be assessed graduated sanctions } \\
\text { by other appropriators, officials accountable to these appropriators, or both }\end{array}$ \\
\hline 6. Conflict-resolution mechanisms & $\begin{array}{l}\text { Appropriators and their officials have rapid access to low-cost local arenas to resolve } \\
\text { conflicts among appropriators or between appropriators and officials }\end{array}$ \\
\hline 7. Minimal recognition of rights to organize & $\begin{array}{l}\text { The rights of appropriators to devise their own institutions are not challenged by } \\
\text { external governmental authorities }\end{array}$ \\
\hline 8. Nested enterprises & $\begin{array}{l}\text { Appropriation, provision, monitoring, enforcement, conflict resolution, and governance } \\
\text { activities are organized in multiple layers of nested enterprises that are connected and } \\
\text { coordinated vertically and horizontally }\end{array}$ \\
\hline
\end{tabular}

7 of 85 sea cucumber licenses are held by central coast communities. Although these resources might be considered well managed from an ecological perspective (Perry et al. 1999, Hand et al. 2008, Anderson et al. 2011, DFO 2012a,b, 2014b), First Nations harvesters and managers envision a reconfiguration of the current institutions and allocations to address the inequities entrenched in the current system.

We describe and compare current and envisioned geoduck and sea cucumber management practices on the BC central coast as expressed by a range of informants and management documents. We use Elinor Ostrom's social-ecological system (SES) framework and CPR design principles (Becker and Ostrom 1995, Ostrom 2009, Cox et al. 2010, Basurto and Nenadovic 2012, McGinnis and Ostrom 2014) to assess the robustness of the current and envisioned institutions. Specifically, we ask: How is the system currently configured? Does this context lend itself to localized management? Are the proposed institutions for resource management likely to be robust? Will they lead to ecologically sustainable and socially equitable outcomes? We then describe the implications of our work to the evolution of CPR design principles. Finally, we discuss the enablers and barriers to the proposed transformation.

\section{Ostrom's social-ecological system framework and common-pool resource design principles}

Elinor Ostrom and others have developed a useful analytical framework for examining the efficacy and outcomes of natural resource governance in various SESs (Fig. 1). The SES framework details four sets of variables that contribute to a central action situation in a given social, economic, ecological, and political setting: the resource system, resource units, governance system, and actors (Ostrom 2009, McGinnis and Ostrom 2014). The action situation is defined as "individuals (acting on their own or as agents of organizations) observe information, select actions, engage in patterns of interaction, and realize outcomes from their interaction" (McGinnis, unpublished manuscript, page 9; McGinnis 2011). Key interactions include harvesting levels, information sharing, deliberation processes, conflicts, investments, lobbying, self-organizing, networking, and monitoring (Ostrom 2009, McGinnis and Ostrom 2014). Outcomes include social (e.g., efficiency, equity, accountability, economic benefits) and ecological (e.g., ecology, biodiversity, resilience, sustainable harvests) performance measures as well as external effects on other SESs. It is at the level of interactions and outcomes that the system can be evaluated by actors or observers and subsequently fed back into the other components of the SES, including the governance system (McGinnis and Ostrom 2014).

Fig. 1. Social-ecological system framework. Source: McGinnis and Ostrom (2014).

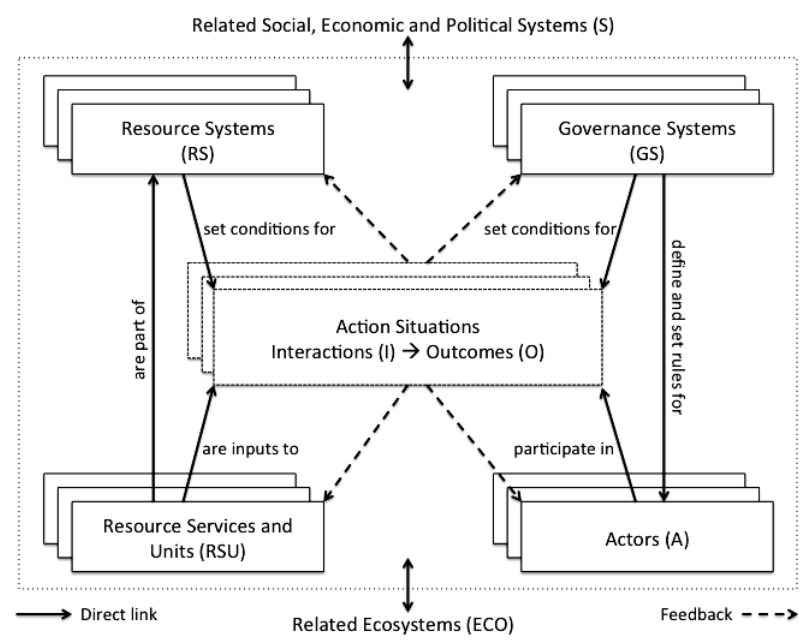


Ostrom and others have drawn on SES studies from different contexts to show that robust CPR governance systems tend to be associated with certain institutional characteristics, including particular rules and structures (Ostrom 1990, Agrawal 2003, Gutiérrez et al. 2011, Basurto and Nenadovic 2012). The set of CPR design principles (Table 1) synthesizes the core factors that affect the likelihood of the long-term survival of an institution that has been developed by local resource users (Cox et al. 2010, Ostrom and Cox 2010). These have been applied and tested extensively through case studies in agriculture (Ostrom 1993, Lam 1999), fisheries (Cudney-Bueno and Basurto 2009, Cinner et al. 2012a), forests (Morrow and Hull 1996, Poteete and Ostrom 2004), water management (Huntjens et al. 2012), and other environments, and corroborated and refined through a recent meta-analysis (Cox et al. 2010). Cox et al. (2010) suggest that these principles are a probabilistic way to assess the potential for success of a CPR system and should be interpreted as diagnostic, rather than prescriptive.

Common criticisms of Ostrom's framework and design principles are that social factors, including trust, legitimacy, and social capital, are missing, as are social mechanisms and processes (e.g., social learning), and external factors such as market integration, as well as historical and cultural context (Agrawal 2003, Cox et al. 2010, Ostrom and Cox 2010). As a result, Ostrom's work tends to overlook power dynamics and historical influences (Johnson 2004, Clement 2010, Whaley and Weatherhead 2014). We understand that the presence or absence of CPR design features should be understood in the context of a complex set of legal, political, social, and cultural institutions, processes, and relationships (Cox et al. 2010). Indeed, in her later work, Ostrom explicitly recognized the roles of norms and heuristics, trust, communication, and large-scale contextual factors in creating conditions for successful CPR management (Ostrom 2007, Ostrom and Cox 2010).

Broad application of these principles and frameworks has allowed for extensive comparisons between SESs and subsequent refinement. While recognizing their limitations, we propose that the SES framework is a useful tool for describing and characterizing issues in a system, and that the CPR design principles are sufficiently developed to serve as a tool for analysis of future institutional scenarios. Many others have used the design principles to assess the adequacy of current or historical local governance institutions (see Cox et al. 2010). However, no studies that we are aware of apply these principles to evaluate the potential robustness of envisioned future institutions, in particular, those that are an attempt to right historical injustices, power imbalances, and inequities in the distribution of rights and benefits while maintaining the sustainability of a resource.

\section{Study context: British Columbia's central coast fisheries governance}

The BC central coast is part of the largest coastal temperate rainforest in the world with diverse marine and terrestrial wildlife. The region is home to four indigenous peoples (First Nations: Heiltsuk, Wuikinuxv, Kitasoo/XaiXais, and Nuxalk) and several more recent settler communities, as well as approximately 30 geographically dispersed recreational lodges and tourism operations. These communities remain economically tied to the natural resources that surround them through fishing, logging, aquaculture, marine transportation, and tourism.
Colonization and globalization have shaped fisheries governance on the BC central coast, with consequent social, economic, cultural, and ecological restructuring (Harris 2001, Jones et al. 2004, Green 2007, Ommer 2007). BC's central coast fisheries fall under the jurisdiction of the federal department of Fisheries and Oceans Canada (DFO), which has the responsibility to regulate and monitor access and allocation of fisheries and aquaculture. However, central coast First Nations (CCFN) have parallel orders of laws and practices that embody knowledge gained from thousands of years of inhabiting this land and seascape (Johnsen 2009).

Before colonization, CCFN managed the lands and waters using systems entrenched in social, cultural, and economic protocols and practices, and developed rich cultures embedded within abundant fisheries that they learned to steward skillfully (Trosper 2003, King 2004, Johnsen 2009). Beginning at the turn of the century, traditional property arrangements and local guardianship laws were subsumed by common-law, open-access systems, which fed thriving primary resource extraction industries. While local First Nations actively participated as fishers and laborers, self-determination and associated traditional fishing rights and practices were eroded. Over the following decades, the open-access system was subsumed by private license and quota management systems that tended to concentrate capital in the hands of an elite minority. Systematic privatization placed decision-making, monitoring, and enforcement authority in the hands of federal agencies and industry. These processes effectively excluded many coastal peoples from profitably accessing or sustainably managing local resources. As a result, the benefits associated with natural resource development in this region have largely not accrued to local residents (King 2004, Edwards et al. 2006, Ommer 2007, Turner et al. 2008, Price et al. 2009, Harris and Millerd 2010, Wiber et al. 2010, Pinkerton and Silver 2011), and $>45 \%$ of local fishers have exited the industry (Ecotrust 2004). With few economic opportunities, central coast residents now experience significantly greater unemployment and health challenges than the rest of the province (Smith and Sterritt 2007).

Canada attempted to initiate more integrated and participatory approaches to coastal management through the 1997 Oceans Act and ensuing Oceans Strategy (Hanson 1998). However, their implementation has proven difficult (Rutherford et al. 2010, Jessen 2011). DFO-led planning for Large Ocean Management Areas, including the Pacific North Coast Integrated Management Area (PNCIMA), has been mired in bureaucratic inconsistencies and a lack of capacity and institutional will (Kearney et al. 2007, Flannery and Ó Cinnéide 2012). First Nations withdrew from the process after DFO unilaterally rescoped the outcomes and deliverables in a manner contrary to the collaborative governance memorandum of understanding (UNESCO Marine Spatial Planning Initiative, Canada PNCIMA: http://www.unesco-iocmarinesp.be/msp around the world/canada_pncima). As a result, Marine Planning Partnership, a complementary initiative involving First Nations and the provincial government, was initiated. This process, now nearing completion, is intended to develop the original PNCIMA work plan for the issues over which the province has jurisdiction. Overall, fisheries "co-management" in BC has tended to involve First Nations as one of many stakeholders or consultants with little power in the decisionmaking process, rather than as independent government authorities of unceded territories (Singleton 2009). 
Despite these challenges, financial, political, and legal support for localized and aboriginal fisheries on the West coast is growing. In particular, an evolving legal context is, to some degree, facilitating the implementation of management visions based on local priorities, laws, and knowledge systems and helping to justify rights and access reallocations (King 2004, Turner et al. 2008, Harris and Millerd 2010, Allison et al. 2012, Capistrano and Charles 2012). Following amendments to Canada's Constitution Act in 1982 (DOJ 2013), section 35(1) recognizes existing Aboriginal rights and was tested through a landmark case in the supreme court of Canada: R. v. Sparrow 1990 (1 S.C.R. 1075). This case affirmed First Nations' constitutional right to fish for food and established priority access for food, social, and ceremonial purposes after conservation requirements were met. R. v. Gladstone 1996 (2 S.C.R. 723) and Ahousaht Indian Band and Nation v. Canada 2009 established an aboriginal right to fish for economic purposes, particularly for species traditionally traded among First Nations. They also recognized potential justifications for the government to alter First Nation commercial fishing rights based on economic and regional fairness and acknowledgement of nonaboriginal historic reliance on and participation in fisheries (Harris and Millerd 2010). Delgamuukw v. British Columbia 1997 (3 S.C.R. 1010) established that title includes jurisdictional authority regarding how the land is used and managed. Taku River Tlingit First Nation v. Ringstad et al. 2000 (77 B.C.L.R. [3d] 310 [B.C.S.C], affirmed 2002, B.C.C.A. 59) and Haida Nation v. British Columbia Ministry of Forests 2004 (S. C.C. 73. 3 S.C.R. 511) also confirmed that the government has a legal duty to consult and, where indicated, accommodate the views of aboriginal peoples in resource management. However, the right to manage and protect resources remains the jurisdiction of the DFO (Harris and Millerd 2010, Capistrano and Charles 2012), and broader economic development priorities have tended to take priority over local economic development. Further, the recent decision by the Supreme Court of Canada to recognize aboriginal land title in Tsilhqot' in Nation v. British Columbia 2014 may have significant implications for future tenure and rights to access and harvest in the marine environment.

Through a variety of processes and initiatives, coastal First Nations aim to regain greater access to fisheries resources and control of their management. CCFN are in the process of creating "institutions to govern resource use ...capital to employ management staff and to fund management and research activities, and educational opportunities to ready community members for employment in marine-related positions" (CCFN 2012:23). Local capacity is increasingly supported by bridging organizations, including the $\$ 120$ million (CAD) Coast Opportunity Fund that supports First Nation initiatives to improve natural resource stewardship and promote environmentally responsible economic development (Price et al. 2009). At the provincial level, the BC First Nations Fisheries Council supports the recognition of aboriginal rights and title regarding the sustainable use and management of aquatic resources through four priorities: sustainable fisheries, capacity development, economic performance, and strategic outreach (FNFC 2012). The current First Nations Fisheries Council strategic plan highlights the importance of priority access as a foundation for sustainable fisheries and communities, as well as that of economic opportunities beyond food, social, and ceremonial purposes
(FNFC 2012). A reconciliation protocol signed between coastal First Nations and the BC provincial government also provides the basis for a more collaborative and coordinated approach to decision-making (CCFN 2009).

On the central coast, the Central Coast Indigenous Resources Alliance (CCIRA) intends to provide a unified CCFN voice on environmental stewardship and resource management. CCIRA has facilitated the development of a harmonized Marine Use Plan that envisions increased access to and benefit from coastal resources, taking up the call for an adaptive, ecosystem-based approach informed by traditional and scientific knowledge. CCIRA is also working to establish shared decision-making structures between First Nations and federal authorities. Through the creation and implementation of marine use plans, a new partnership of First Nations is working to enable greater participation in marine-based industries, including commercial and sport-fishing, seafood processing, shellfish aquaculture, and tourism. They propose a broad range of institutions intended to increase self-determination in local resource management (CCFN 2012). As a result, CCFN have established local integrated resource management offices and are developing capacity within their communities for stewardship, monitoring, conservation, and restoration based on local priorities and practices, including indigenous laws (Brown and Brown 2009, Jones et al. 2010), promoting resilience and sound ecological management (Berkes et al. 2000, Trosper 2003, Haggan et al. 2006, Turner and Berkes 2006).

\section{METHODS}

Our research project emerged from a course on social-ecological resilience co-created by Heiltsuk and Wuikinuxv resource managers and university faculty. The research process and protocol was designed collaboratively with the intention of supporting local resource management efforts. We used multiple methods, including secondary document reviews, observations of a meeting, semi-structured interviews, and key-informant informational meetings in May-June 2012, with additional follow-up with key informants in 2013.

\section{Review of non-peer-reviewed literature}

We reviewed select planning and policy documents, including materials related to the CCFN Marine Use Plan, DFO integrated management plans, and materials from other relevant actors' websites and libraries to understand the historical, political, economic, social, and governance context.

\section{Observation: Coastal Stewardship Network annual meeting}

As invited observers, we recorded key fisheries-related issues raised at a four-day annual meeting of the Coastal Guardian Watchmen (CGW) in May 2012. The CGW and associated Coastal Stewardship Network support the activities of First Nations resource practitioners involved in monitoring on the North and central coasts (Turner and Bitonti 2011; Coastal Stewardship Network, http://coastalguardianwatchmen.ca). The network also plays an important role in promoting understanding and collaboration between First Nations around resource stewardship. A coordinated presence on the ground, including a regionally harmonized monitoring system and associated data collection and analysis tools, has proven to be valuable for increasing local monitoring capacity and local stewardship 
Fig. 2. Central coast First Nations sea cucumber (SC) and geoduck (GD) social-ecological system. Adapted from Ostrom (2009).

\section{Social, Economic and Political Settings Federal control over fisheries}

First Nations want more autonomy and local management

First Nations have prioritized marine-industry economic development

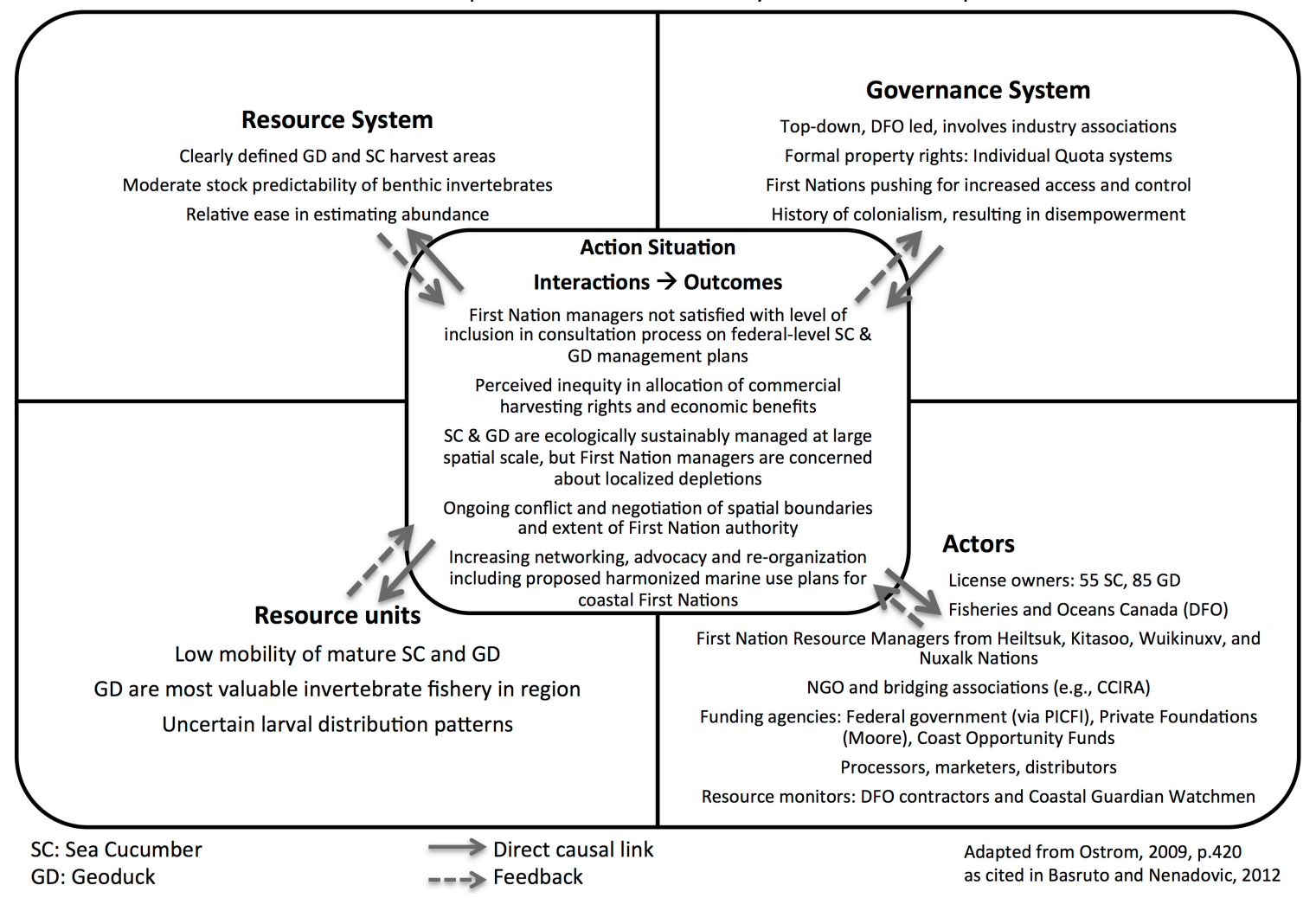

legitimacy. Attending this meeting gave us insight into local resource management, including current regional debates and priorities, and informed our research questions. Throughout the meeting, we took detailed notes on our observations and conversations.

\section{Semi-structured interviews}

Using purposive sampling, we identified and contacted key actors in central coast sea cucumber and geoduck management. We conducted one-on-one, in-person, semi-structured interviews ( $N$ $=3$ ) and informational meetings $(N=2)$ with Heiltsuk resource managers, a management leader from each of the three surrounding First Nations (i.e., Nuxalk, Wuikinuxv, Kitasoo; $N$ $=3$ ), and people working in regional capacity-building $(N=1)$ and natural resource planning organizations $(N=2)$, as well as a relevant regional-level manager at DFO (by phone). Interviews addressed elements of the SES framework, the CPR design principles, as well as enablers and barriers to the transformation of sea cucumber and geoduck management. We transcribed and returned interview notes to participants when requested.

\section{Analysis}

Coding of interview transcripts, meeting notes, and select documents was conducted using qualitative analysis software
(Dedoose) to identify common themes. Using results from the preceding methods, we sketched the main elements of Ostrom's SES framework (Ostrom 2009; Fig. 2). Bounding our study to CCFN participation in geoduck and sea cucumber fisheries management, we identified and explored resource systems and units, relevant actors, governance processes, and interactions and outcomes of the system. We paid particular attention to topics related to history, equity, and power. We coded for characteristics of people associated with management systems that would improve First Nations involvement in and benefit from geoduck and sea cucumber fisheries. We systematically noted when elements of Ostrom's principles arose while remaining open to emergent ideas and concepts. We open-coded for enablers and barriers to improving geoduck and sea cucumber management systems. To verify results, early drafts of the paper were reviewed by key collaborators, including the Heiltsuk Integrated Resource Management Office, CCIRA, and Coastal Stewardship Network managers.

\section{RESULTS}

We next describe the key components of sea cucumber and geoduck SESs and identify perceived issues with the current system. We then characterize the current and envisioned sea 
cucumber and geoduck governance systems, as described by the informants and associated planning and policy documents, and analyze the extent to which each of these systems aligns with Ostrom's CPR principles.

\section{Current management system}

Our initial social-ecological inventory details the general setting, resource system, governance system, resource units, actors, and key interactions and outcomes associated with the management of sea cucumber and geoduck (Fig. 2). We discussed some of these items previously (Study context: British Columbia's central coast fisheries governance) and, due to space restrictions, do not expand upon all of them here. However, we outline the main issues used to rationalize a reconfiguration of the system.

BC's geoduck and sea cucumber fisheries are managed by DFO in collaboration with their respective harvester associations (Underwater Harvesters Association and Pacific Sea Cucumber Harvesters Association), which comprise license holders, crew members, processors, and wholesalers (DFO 2014b). With an annual landed value of approximately $\$ 40$ million (CAD), geoduck is BC's most valuable invertebrate fishery (Khan 2006). The annual landed value of sea cucumber is approximately $\$ 1.7$ million (CAD). Given the prohibitive costs and low availability of geoduck and sea cucumber licenses ( $\$ 3.25$ million and $\$ 300,000$ CAD per license, respectively) and low First Nations license ownership (3/55 for geoduck, 7/85 for sea cucumber), First Nations are largely excluded from managing, accessing, or benefiting from these fisheries (Nelson 2011).

First Nations managers expressed frustration with current and historical decision-making processes regarding benthic resources. Much of the decision-making power in these fisheries is held by distantly located license holders concerned about their bottom line, as opposed to local fishers who might witness the effects of overharvesting. Current relationships between First Nations governments and managers and other actors, including industry associations, commercial harvesters, license-holders, and federal agents, are mixed but often characterized by tension, poor communication, and insufficient support for meaningful engagement. Although DFO's integrated management plans are officially corroborated by First Nations, CCFN interviewees were dissatisfied with an entrenched federal regime that emphasizes resource privatization, privileging industry over community priorities, and felt that the DFO consultation process did not effectively incorporate their input. They were resistant to participating in a symbolic consultation process that accorded them little power to change management practices and neglected to recognize that their legal status differs from that of stakeholder groups. A letter of intent was recently signed to the effect that First Nations will be consulted prior to other stakeholder groups (K. Cripps, Central Coast Indigenous Resource Alliance, personal communication). Although opportunities for geoduck aquaculture are increasing, First Nations similarly felt that their interests and involvement are being inadequately prioritized in this arena.

Because of the legacy of colonial disenfranchisement and disempowerment, local management, science, and leadership capacity among CCFN is limited, but growing. CCFN stewards hope that through local Integrated Resource Stewardship offices and regional Coastal Guardian Watchmen programs, their presence on the ground will make a valuable contribution to regional ecological conservation while bolstering community identity, pride, and capacity. Currently, sea cucumber and geoduck monitoring is conducted on site by DFO and harvesting associations, and enforcement is perceived to be minimal. However, for $>10$ years, CCFN (primarily Kitasoo Nation) have been have been developing and collecting rigorous data on sea cucumber and geoduck ecology, developing fine-scale local knowledge and scientific capacity in the region. This increased capacity has increased local legitimacy to the point that local CCFN managers and authorities were able to counteract a DFO decision to open a contentious sea cucumber harvesting area (see Box 1).

Box 1: Asserting local authority: sea cucumber management in Kitasoo territory

Spatial zoning boundaries on the British Columbia central coast are currently under negotiation as First Nations finalize their spatial marine use plans. Notably, an ongoing controversy around the expansion of sea cucumber harvesting in Kitasoo territory may shape future debates around management authority. In this case, members of the Kitasoo Nation have worked with biologists to collect baseline data and conduct experiments on sea cucumber population dynamics since 1994. In 1997, they led the implementation of a long-term experimental fishing area examining the effects of different exploitation rates on stock dynamics in traditional Kitasoo territory. When the federal department of Fisheries and Oceans Canada (DFO) decided to open the area to sea cucumber harvesting, the Kitasoo, based on their commitment to setting aside $\sim 30 \%$ of their marine territory for on-going sea cucumber research and conservation, threatened blockades and legal action. In the absence of an agreement between parties, Kitasoo then circumvented DFO authority by contacting harvesters directly and requesting that they not enter the contested areas. Based on the strength of existing relationships and their strong foundation of local science and monitoring, the Kitasoo defended their sea cucumber conservation area. Central coast First Nations and DFO have been attempting to resolve outstanding spatial management issues, but have not been able to come to a final agreement.

\section{Envisioned changes in social-ecological system management}

Our analysis of interviews, planning, and management documents revealed that CCFN are developing the plans and capacities to actualize their goals of self-determination through the stewardship of local resources, including sea cucumber and geoduck. CCFN resource managers envisioned greater involvement in economic benefits of resource use and in the sustainable management of traditional territories. They often spoke of building a strong foundation for future generations, and wanted local resources to benefit their communities. They also felt that that CCFN ought to be more involved in commercial fisheries management in their traditional territories, and worried that DFO capacity, both institutional and financial, was insufficient to promote meaningful engagement. 
CCFN managers and their allies were largely optimistic about the future localized management of benthic resources in the region. They were proud of the vision and hard work that had gone into the creation of local and regional marine use plans, and often underlined their congruence with indigenous laws and practices. They also had a high level of confidence in their communities' capacity to implement plans. They were enthusiastic about the establishment of new relationships with the province and between Nations, and supportive of the role of bridging organizations such as CCIRA, First Nations Fisheries Council, and Marine Planning Partnership in moving local management agendas forward. However, they were concerned about whether these marine spatial and marine use plans would be implemented because there is considerable uncertainty regarding the extent to which the federal government will recognize and support these plans. They were also in favor of using legal means, including aboriginal rights and title in conjunction with use and occupancy data, to support their efforts to regain control over local resources.

CCFN managers also expressed interest in working directly with industry, aiming to gain direct access to those who influence decision-making outcomes as a stepping-stone to greater control of resources and revenues. They aimed to leverage resources to increase institutional and human capacity by way of licensing programs, reconciliation protocols, and revenue-sharing agreements with provincial and federal governments, who derive significant revenues and taxes from the resource wealth of the territory. They also foresaw the potential of value-added fisheries processing and geoduck aquaculture to create diversified, sustainable development opportunities at the local level, as well as the potential of impact-benefit agreements with businesses operating in the region. Similarly, CCIRA envisions a number of mechanisms in support of increased local participation in these fisheries, including: enabling revenue sharing agreements and equitable participation in economic development and capacity building; acquiring resource tenures and licenses through government negotiation, existing programs, and market buyback; developing partnerships with industry, environmental organizations, and other third parties; and affirming aboriginal rights and title to lands and waters (CCIRA 2012).

Interviewees also recognized practical challenges to local involvement in benthic resource management, including capacity needs in management, scientific, and technical fields, and in several communities, lack of continuity in leadership. The prohibitive cost of commercial licenses and lack of access to other capital-generating opportunities also pose challenges. Other barriers include issues with legal and policy environments, governance and decision-making processes, information and knowledge valuation, relationships, capital and funding, and capacity.

\section{Common-pool resource design principles on the central coast of British Columbia}

Many of the sea cucumber and geoduck management priorities identified by the informants relate directly to Ostrom's CPR design principles, yet current and envisioned governance systems differ markedly (Table 2). Overall, CCFN's envisioned institutions appear largely to match the CPR design principles. Because of space restrictions, we only expand on a few of the envisioned changes.
The institutional analysis literature describes a problem of fit as the lack of effective and appropriately scaled social institutions at the nexus of the biophysical domains where they operate (Folke et al. 2007). For example, the second CPR principle (2a), which stipulates that appropriation rules be related to local conditions, is not largely met by the current system as we understand it. On the central coast, a scalar mismatch of local conditions and federal management units is illustrated by sea cucumber management: quotas are assigned to large areas, but harvesters tend to concentrate their effort in small areas, leading to localized depletion. Similarly, geoduck regulations have recently shifted to allow harvesting in all areas and transfer of quotas between areas, which indicates to local First Nations managers that management priorities are not taking declining geoduck stocks into account. In both cases, the current management systems were perceived by the local informants to be exacerbating localized and serial ecosystem depletion similar to that experienced by abalone in the region. In future, CCFN managers would prefer to manage using spatially smaller units to minimize impact and maximize dispersion and growth, as well as localized monitoring and evaluation to understanding of the relationships between those units.

Design principles 3 and 4 (regarding collective-choice arrangements and monitoring) are not well supported by the current management regime. Local control over operational rules and monitoring processes is minimal, and decision-makers and monitors are not accountable to those with the most to gain or lose from the resources' condition (local communities/future generations). CCFN managers and their allies would prefer to see decision-making authority and monitoring devolved to the local level. Similarly, appropriate conflict resolution mechanisms are lacking in the current management system, where disappointment and disillusionment around consultation processes and engagement have recently resulted in conflict and costly lawsuits over these resources.

The seeds of a nested management system, described in principle 8, are already planted and evolving on BC's central coast: four distinct and independent First Nations are already working together on harmonized marine planning and have elected to coordinate stewardship efforts and priorities through CCIRA. Although their ultimate goal may be self-determination, they are also willing to work with other actors, including provincial and federal governments and industry.

\section{DISCUSSION}

The management and governance of marine fisheries on the Pacific Coast of Canada is evolving, and coastal First Nations are active in reshaping the system. After generations of marginalization, First Nations in BC are rebuilding community capacity, governance capabilities, and management institutions. They are exerting powerful claims for rights and title over the lands and waters of their traditional territories, demanding adaptive governance through collaborative marine use and spatial planning, and self-organizing in novel ways. Here, we used the SES framework and CPR design principles commonly associated with robust SESs to describe and analyze current and envisioned co-management of commercial sea cucumber and geoduck fisheries along the central coast of BC, Canada, with particular attention to First Nation managers' aspirations for improving 
Table 2. Common-pool resource design principles in relation to central coast First Nations sea cucumber and geoduck management context and future goals. GD = geoduck, $\mathrm{SC}=$ sea cucumber, FN = First Nation.

\begin{tabular}{ll}
\hline \hline Design principle & Present context \\
\hline $\begin{array}{l}\text { 1A. Clearly defined user } \\
\text { boundaries }\end{array}$ & $\begin{array}{l}\text { Commercial withdrawal rights are clearly delineated: Individual } \\
\text { Vessel Quotas for GD and Individual Quotas for SC }\end{array}$ \\
\end{tabular}

1B. Clearly defined resource boundaries

2A. Congruence between appropriation and provision rules and local conditions

2B. Inputs proportional to benefits

3. Collective-choice arrangements

4A. Monitoring users

4B. Monitoring resource
Large federal management areas are clearly delineated ${ }^{\dagger}$

GD and SC exist in relatively distinct beds/areas known to and recognized by appropriators ${ }^{\dagger}$; reproductive functions linking these units are poorly understood ${ }^{\ddagger}$

Concern about localized over-harvesting in some SC Quota Management Areas ${ }^{\dagger}$

Misfit between harvest area size and harvesting practices is perceived to cause localized SC depletion ${ }^{\S}$

Local FN are affected by SC and GD harvesting practices, but the prohibitively high cost of licenses and limited entry prevents local participation in appropriation beyond food, social, and ceremonial purposes; FN own $<10 \%$ of licenses in these fisheries

Insufficient resource monitoring at a fine spatial scale to inform localized plans ${ }^{\S}$

FN have low input into and little benefit from GD and SC fisheries $^{\sharp}$

DFO and Harvesters Associations set operational rules with minimal $\mathrm{FN}$ input ${ }^{\S}$

FN have limited say about how benthic resources on their territory are managed; there are few FN license holders and thus representation in decision-making is limited ${ }^{\S}$

Inclusion rules for stakeholder negotiations are considered inappropriate by $\mathrm{FN}^{\S}$

DFO and industry organizations conduct their own dockside monitoring, often employing local labor ${ }^{\ddagger}$

Current monitors are accountable to nonlocal license holders, and their associations, market, and economic considerations are a high priority

DFO coordinates GD and SC stock assessments ${ }^{\ddagger}$

Harvests for GD are set at $1.2-1.8 \%$ of biomass estimates for each bed based on feedback from ecological monitoring and harvesters ${ }^{\ddagger}$

Harvests for SC under the current management plan are $10 \%$ on a 3 -yr rotation ${ }^{\ddagger}$
Central coast First Nations' management vision

Change in access and harvesting rights: target $50 \%$ central coast FN participation in commercial activities $^{\dagger}$

Change boundaries to reduce size of harvesting and management units ${ }^{\dagger}$

Alter distribution of harvesting effort to reduce likelihood of localized over-harvesting ${ }^{\dagger}$

Significant input from local FN managers via harmonized, FN-led marine use plans covering SC and $\mathrm{GD}^{\dagger}$

Resource-appropriate quota management areas for $\mathrm{SC}$; move the fleet more regularly to prevent localized over-harvest ${ }^{\dagger}$

Consideration and use of traditional ecological knowledge, use, and occupancy as well as local science in management ${ }^{\dagger}$

Increase local access to and benefits from SC and GD fisheries ${ }^{\dagger}$

Increase local access to and benefits from $\mathrm{SC}$ and GD fisheries ${ }^{\dagger}$

Increase participation in governance of fisheries ${ }^{\dagger}$

Joint governance of benthic resources with increased local input, including a high degree of FN input regarding operational rules ${ }^{\dagger}$

Improved local monitoring capacity on-site ${ }^{\dagger}$

Collect fees from industry operators on territory to finance monitoring and conservation ${ }^{\dagger}$

Improved local monitoring capacity on-site, including increased science capacity at the local scale $^{\dagger}$ 
5. Graduated sanctions

6. Conflict-resolution mechanisms

7. Minimal recognition of rights to organize

8. Nested enterprises
According to FN informants, enforcement is insufficient; DFO lacks resources to monitor adequately and apply sanctions in remote coastal areas ${ }^{\ddagger}$

FN resource stewards do not have authority to enforce local rules or apply sanctions

FN do not feel their concerns are taken into consideration during management consultation processes, which has led to escalated conflict in the recent past (e.g., legal action, blockades)

Laws support claims and increased access, but legal conflict resolution mechanisms are expensive

Coastal community groups have the right to organize; however, they do not have authority to implement their decisions ${ }^{\ddagger}$

FN are working toward co-jurisdictional agreements with DFO and other regional and federal authorities ${ }^{\ddagger}$

Top-down bureaucracy and entrenched federal institutions resist
change; there is a disconnect between political and operational
scales

Communication and collaborative capacity between scales needs improvement $^{\S}$

New relations between FN and across scales (e.g., funders, nongovernmental organizations, and provincial governments) are being facilitated by bridging organizations (e.g., Central Coast Indigenous Resources Alliance and FN Fisheries Council) and planning processes (Marine Planning Partnership)
Local monitors (e.g., Coastal Stewardship Network) with authority to enforce rules and regulations

For local FN violators, sanctions would be graduated and restorative as appropriate

Federal government-FN government negotiations occur before multi-stakeholder consultation processes

Co-jurisdictional agreements provide increased authority to implement local marine use plans ${ }^{\dagger}$

Improved local management capacity by $\mathrm{FN}^{\dagger}$

Improved relationships and trust between $\mathrm{FN}$ and industry, government, and other $\mathrm{FN}^{\dagger}$

Local management plans nested within horizontal bridging organizations (e.g. Central Coast Indigenous Resources Alliance, Marine Planning Partnership), created in collaboration with provincial and federal governments and industry ${ }^{\dagger}$

\footnotetext{
${ }^{\dagger}$ Congruence between a design principle and current management context or future goals.

${ }^{\ddagger}$ Marginal congruence between a design principle and current management context or future goals.

${ }^{\S}$ Incongruence between a design principle and current management context or future goals.
}

them. BC stock assessments maintain that the current system of sea cucumber and geoduck fisheries is relatively ecologically sustainable at a province-wide spatial scale (Hand et al. 2008, Anderson et al. 2011, DFO 2012a,b). Historical processes, however, have led to a situation where local First Nations perceive that they are not adequately involved in decision-making processes nor allocated a fair share of harvesting rights and benefits. Further, both geoduck and sea cucumber harvesters perceive that abundance and catch-per-effort have been decreasing and understand the top challenges to the industries include over-fishing and an owner-operator system that priviledges the interests of licence holders and marginalizes the representation of harvesters (O'Regan 2014).

These perceived inequities have led First Nations to envision a reconfiguration of the current management institutions to improve local involvement, allocations, and socioeconomic outcomes. Our research and analysis shows that the CCFN envision improvements in sea cucumber and geoduck management that largely align with Ostrom's CPR design principles. This suggests that the proposed governance institutions would be relatively robust. However, continued attention would be needed to nest these envisioned institutions effectively within broader marine management and fisheries governance structures and processes. Cudney-Bueno and Basurto (2009:e6253) conclude that local management efforts are facilitated by "rewarding local effective management with formal cross-scale governance recognition and support." Increased CCFN authority and reallocation of harvesting rights also have the potential to empower residents to obtain long-lasting social and economic benefits.

Further, our analysis suggests that First Nations involvement in geoduck and sea cucumber management on BC's central coast could potentially result in the successful long-term management of these resources. The CPR literature demonstrates that in many contexts, but certainly not all, local groups with strong social capital, ownership, and participation have the greatest incentive to manage resources without degrading them over time (Cox et al. 2010). Particularly in remote and poorly serviced areas such as BC's central coast, local management and monitoring might decrease the likelihood of over-harvesting (Pinkerton and John 2008). Engagement in local stewardship and monitoring can support adaptive management practices based on local knowledge and observation, reinforcing cooperation and resilience (Cudney-Bueno and Basurto 2009). Further, local engagement in data collection has been shown to promote environmental responsibility and support the integration of 
western science with traditional ecological knowledge (Pinkerton and John 2008, Wiber et al. 2009, Gelcich et al. 2010). However, we cannot be entirely certain that the envisioned governance regime would result in either equivalent or more effective resource management than the current top-down regime.

This leads us to an important point. Transforming a system of natural resource management that is relatively stable and sustainable may be hard to justify, especially for a government agency whose primary mandate includes maintaining sustainable aquatic ecosystems and economic growth (DFO 2014a). However, such a transformation may be necessary to right historical injustices, power imbalances, and inequitable distribution of rights and benefits, and to assure conservation goals over long time horizons. Prominent enablers of the transformation include articulating and communicating a clear vision of future management priorities, strengthening cross-scale relationships, building on current partnerships, increasing local capacity in science and management, and having a strong legal basis for pursuing local management goals and the just redistribution of commercial harvesting rights to First Nations (Appendix 1). Potential barriers and challenges include the need to modify DFO consultation structures and processes, limited (but growing) science and management capacity in many First Nations communities, and limited access to capital. A significant barrier to redistributing commercial harvesting rights is the cost of purchasing a harvesting license, which in 2011 was $\$ 3.25$ million for a geoduck license and $\$ 300,000$ for a sea cucumber license. A recent study involving $\mathrm{BC}$ sea cucumber harvesters suggests that one solution to this issue could be that licenses be issuable and transferrable only to local harvesters (O'Regan 2015).

Important lessons might also be gleaned from successful CPR governance transformations elsewhere. For example, the governance of the Chilean loco, a benthic marine invertebrate fishery, was transformed from an open-access regime to Territorial User Rights Fisheries that successfully transferred user rights and responsibilities to fisher collectives (Gelcich et al. 2010). Bridges and barriers to the success and legitimacy of local clam fisheries governance on the west coast of Vancouver Island, BC has also been studied extensively (Pinkerton and John 2008, Pinkerton and Silver 2011). Marine planning on Haida Gwaii, $\mathrm{BC}$ has involved capacity building to support the development of co-governance and incorporation of Haida values and ethics into integrated oceans management (Jones et al. 2010).

This study is a novel application of the SES framework to describe and identify issues in governance of a given SES and of the CPR design principles to analyze envisioned institutions. Although this may not be the intended use of the frameworks, we advocate for increased flexibility in applications of these analytical tools and an extension of the range of methods used, contexts explored, and temporal and spatial scales analyzed. For example, we advocate for their application to analysis of broad-scale and multi-stakeholder ecosystem-based management and marine spatial planning processes such as those currently occurring on the BC coast (West Coast Aquatic marine spatial planning: $\underline{\text { http:// }}$ westcoastaquatic.ca/marine-spatial-planning/; DFO PNCIMA initiative: http://www.pncima.org/; Marine Planning Partnership for the North Pacific coast: http://mappocean.org/). In our case study, the SES framework helped us to organize and evaluate issues in governance processes and social outcomes based on perceptions of First Nations managers. The SES framework can take into account important contextual factors. We attempted to address previous critiques related to the limited role of historical context and power dynamics in CPR literature (e.g., Johnson 2004, Clement 2010, Whaley and Weatherhead 2014) by paying close attention to historical dispossessions and current discourses related to reinvigorating coastal resource management by and for First Nations, as well as to issues of equity.

While providing neither decision rules nor policy prescriptions, the CPR design principles are a potentially useful tool for assessing the likelihood that envisioned institutions will be robust. As such, the CPR design principles might also provide a useful framework to guide future visioning or backcasting processes that seek to re-imagine or redesign management systems. However, the CPR design principles cannot answer whether future institutions will lead to the sustainability of resources or ecosystems. Future research in this area might also focus on how to achieve a balance between ecological and social outcomes through institutional transformation. The CPR design principles might also be further elaborated through testing and incorporating thinking and indicators from scholarship on socialecological resilience (Berkes et al. 2003), adaptive co-management (Armitage and Plummer 2010), adaptive capacity (Armitage and Plummer 2010, Marshall et al. 2010, Bennett et al. 2014), and social and anticipatory learning (Tschakert and Dietrich 2010, Huntjens et al. 2012). Particular attention should be paid to diversity and flexibility, social and policy learning, integrating diverse knowledges, and equity in access to assets, as well as to addressing unexpected shocks and complex cross-scale interactions.

This research has several important limitations and assumptions. First, our study was informed primarily by interviews with and the perspectives of CCFN resource managers and their collaborators because it is ultimately intended to address and evaluate the local management agenda of CCFN. We did, however, interview one DFO representative and review available management documents to understand the broader context. Secondly, our sample size was limited, and the following groups were not interviewed: United Harvesters Association and Pacific Sea Cucumber Harvesters Association. This was because of limited resources and the short time frame of the project. Third, our research and analysis could have been more explicit about the roles of norms and discourse in shaping envisioned institutions. Fourth, the results of the CPR institutional analysis presented here can only be suggestive (e.g., regarding robustness and sustainability) because the focus is on a future state. Fifth, this analysis is still somewhat short on consideration of macro-scale factors such as markets.

\section{CONCLUSION}

In this analysis, we focused on more explicit inclusion of social equity and historical context while assessing SESs and envisioned CPR governance. We compared current and envisioned geoduck and sea cucumber management systems as a case study of increased First Nations involvement in fisheries governance. The SES framework helped us to understand and articulate historical and social equity considerations, and the CPR design principles were a useful way to consider the robustness of envisioned 
institutions. Our study suggests that increasing First Nations participation in benthic resource governance and commercial activities has the potential to promote social and economic benefits for previously disadvantaged communities, thus moving toward addressing historical injustices and linked inequities. The envisioned governance system is likely to result in a robust SES that supports healthy ecosystems for the benefit of future generations. However, there are significant barriers to the envisioned institutional transformation, including capacity shortfalls and structural factors.

In a review of coastal resource governance, Kearney et al (2007) noted that to be successful, participatory management in Canada requires a paradigm shift. Through creating marine use plans and articulating visions for greater commercial access to and participation in managing marine resources, $\mathrm{CCFN}$ are devising such a shift. However, for sea cucumber and geoduck fisheries, the current ecological stability of the resource, combined with significant local and external barriers and institutional inertia, may mean that a slow transition is a more realistic expectation than a transformation. The dynamics of this SES are a test of the extent to which federal authorities will demonstrate adaptive governance capacity. Will flexibility, inclusiveness, diversity, and innovation be encouraged in fisheries governance? Our research calls attention to ways forward for First Nations and the governments of Canada, acting at various local, regional, provincial, and national scales, to negotiate equitable and sustainable management of natural resources.

Responses to this article can be read online at: http://www.ecologyandsociety.org/issues/responses. php/7123

\section{Acknowledgments:}

We thank the Coastal Guardian Watchmen Network (now Coastal Stewardship Network) 10th Annual Meeting participants and organizers for inviting us to observe this event. We also thank the interviewees who generously gave their time. We gratefully acknowledge the Hakai Beach Institute for hosting the Simon Fraser University course on social-ecological resilience. Our instructors, particularly Anne Salomon, and students in the field course enriched our ideas. Our sincere appreciation also extends to the Heiltsuk Integrated Resource Management office for their warm reception and stimulating dialog about our research projects. We also thank Ken Cripps from Central Coast Indigenous Resource Alliance and Claire Hutton from the Coastal Stewardship Network for feedback on early drafts of the manuscript.

\section{LITERATURE CITED}

Agrawal, A. 2003. Sustainable governance of common-pool resources: context, methods, and politics. Annual Review of Anthropology 32:243-262. http://dx.doi.org/10.1146/annurev. anthro.32.061002.093112

Allison, E. H., B. D. Ratner, B. Åsgård, R. Willmann, R. Pomeroy, and J. Kurien. 2012. Rights-based fisheries governance: from fishing rights to human rights. Fish and Fisheries 13(1):14-29. http://dx.doi.org/10.1111/j.1467-2979.2011.00405.x

Anderson, S. C., J. M. Flemming, R. Watson, and H. K. Lotze. 2011. Serial exploitation of global sea cucumber fisheries. Fish and Fisheries 12(3):317-339. http://dx.doi.org/10.1111/ j.1467-2979.2010.00397.x

Armitage, D., and R. Plummer. 2010. Adaptive capacity and environmental governance. Springer, Berlin, Germany. http://dx. doi.org/10.1007/978-3-642-12194-4

Armitage, D. R., R. Plummer, F. Berkes, R. I. Arthur, A. T. Charles, I. J. Davidson-Hunt, A. P. Diduck, N. C. Doubleday, D. S. Johnson, M. Marschke, P. McConney, E. W. Pinkerton, and E. K. Wollenberg. 2009. Adaptive co-management for socialecological complexity. Frontiers in Ecology and the Environment 7(2):95-102. http://dx.doi.org/10.1890/070089

Basurto, X., and M. Nenadovic. 2012. A systematic approach to studying fisheries governance. Global Policy 3(2):222-230. http:// dx.doi.org/10.1111/j.1758-5899.2011.00094.x

Becker, C. D., and E. Ostrom. 1995. Human ecology and resource sustainability: the importance of institutional diversity. Annual Review of Ecology and Systematics 26(1):113-133. http://dx.doi. org/10.1146/annurev.ecolsys.26.1.113

Bennett, N. J., P. Dearden, G. Murray, and A. Kadfak. 2014. The capacity to adapt? Communities in a changing climate, environment, and economy on the northern Andaman coast of Thailand. Ecology and Society 19(2): 5. http://dx.doi.org/10.5751/ ES-06315-190205

Berkes, F. 2009. Evolution of co-management: role of knowledge generation, bridging organizations and social learning. Journal of Environmental Management 90(5):1692-1702. http://dx.doi. org/10.1016/j.jenvman.2008.12.001

Berkes, F. 2012a. Implementing ecosystem-based management: evolution or revolution? Fish and Fisheries 13(4):465-476. http:// dx.doi.org/10.1111/j.1467-2979.2011.00452.x

Berkes, F. 2012b. Sacred ecology: traditional ecological knowledge and resource management. Taylor and Francis, Philadelphia, Pennsylvania, USA.

Berkes, F., J. Colding, and C. Folke. 2000. Rediscovery of traditional ecological knowledge as adaptive management. Ecological Applications 10(5):1251-1262. http://dx.doi. org/10.1890/1051-0761(2000)010[1251:ROTEKA]2.0.CO;2

Berkes, F., J. Colding, and C. Folke, editors. 2003. Navigating social-ecological systems: building resilience for complexity and change. Cambridge University Press, Cambridge, UK.

Brown, F., and K. Brown. 2009. Staying the course, staying alive: coastal First Nations fundamental truths: biodiversity, stewardship and sustainability. Biodiversity BC, Victoria, Canada.

Capistrano, R. C. G., and A. T. Charles. 2012. Indigenous rights and coastal fisheries: a framework of livelihoods, rights and equity. Ocean and Coastal Management 69:200-209. http://dx.doi. org/10.1016/j.ocecoaman.2012.08.011 
CCFN [Central Coast First Nations]. 2009. Central Coast First Nations BC reconciliation protocol. Province of British Columbia, Victoria, Canada.

CCFN [Central Coast First Nations]. 2012. Central Coast First Nations Marine Use Plan executive summary. CCFN, Vancouver, Canada.

CCIRA [Central Coast Indigenous Resource Alliance]. 2012. Central coast First Nations Marine Use Plan executive summary. Central Coast Indigenous Resource Alliance, Vancouver, Canada. [online] URL: http://ccira.ca/media/documents/pdf/ central-coast-executive-summary-email.pdf.

Cinner, J. E., X. Basurto, P. Fidelman, J. Kuange, R. Lahari, and A. Mukminin. 2012b. Institutional designs of customary fisheries management arrangements in Indonesia, Papua New Guinea, and Mexico. Marine Policy 36(1):278-285. http://dx.doi. org/10.1016/j.marpol.2011.06.005

Cinner, J. E., T. R. McClanahan, M. A. MacNeil, N. A. J. Graham, T. M. Daw, A. Mukminin, D. A. Feary, A. L. Rabearisoa, A. Wamukota, N. Jiddawi, S. J. Campbell, A. H. Baird, F. A. Januchowski-Hartley, S. Hamed, R. Lahari, T. Morove, and J. Kuange. 2012a. Comanagement of coral reef social-ecological systems. Proceedings of the National Academy of Sciences 109 (14):5219-5222. http://dx.doi.org/10.1073/pnas.1121215109

Clement, F. 2010. Analysing decentralised natural resource governance: proposition for a "politicised" institutional analysis and development framework. Policy Sciences 43(2):129-156. http://dx.doi.org/10.1007/s11077-009-9100-8

Cox, M., G. Arnold, and S. Villamayor Tomás. 2010. A review of design principles for community-based natural resource management. Ecology and Society 15(4): 38. [online] URL: http:// www.ecologyandsociety.org/vol15/iss4/art38/.

Cudney-Bueno, R., and X. Basurto. 2009. Lack of cross-scale linkages reduces robustness of community-based fisheries management. PLoS One 4(7): e6253. http://dx.doi.org/10.1371/ journal.pone.0006253

DFO [Department of Fisheries and Oceans]. 2012a. Integrated fisheries management plan summary: sea cucumber (Parastichopus californicus) by dive Pacific region. Fisheries and Oceans Canada, Nanaimo, Canada. [online] URL: http://www.pac.dfo-mpo.gc. ca/fm-gp/mplans/2012/sea_cucumber-holothurie-2012-eng.pdf.

DFO [Department of Fisheries and Oceans]. 2012b. Status update of wild British Columbia geoduck stocks, 2011. Science advisory report 2011/081. Fisheries and Oceans Canada, Nanaimo, Canada. [online] URL: http://www.dfo-mpo.gc.ca/csas-sccs/ Publications/SAR-AS/2011/2011 081-eng.pdf.

DFO [Department of Fisheries and Oceans]. 2014a. Fisheries and Oceans Canada mission, vision and values. Fisheries and Oceans Canada, Ottawa, Canada. [online] URL: http://www.dfo-mpo.gc. ca/about-notre-sujet/org/vision-eng.htm.

DFO [Department of Fisheries and Oceans]. 2014b. Integrated fisheries management plan summary: geoduck and horse clam, Pacific region, 2014. Fisheries and Oceans Canada, Nanaimo, Canada. [online] URL: http://www.pac.dfo-mpo.gc.ca/fm-gp/ mplans/2014/geoduck-panope-sm-2014-eng.pdf.
DOJ [Department of Justice]. 2013. A consolidation of the Constitution Acts 1867 to 1982. Government of Canada, Ottawa, Canada. [online] URL: http://laws-lois.justice.gc.ca/eng/const/ const_index.html.

Ecotrust. 2004. Catch-22: conservation, communities and the privatization of $B C$ fisheries. Ecotrust, Vancouver, Canada. [online] URL: http://ecotrust.ca/fisheries/landmark-study-conservationcommunities-and-privatization-bc-fisheries.

Edwards, D. N., A. J. Scholz, E. E. Tamm, and C. Steinback. 2006. The catch 22 of licensing policy: socio-economic impacts in British Columbia's commercial ocean fisheries. Pages 65-76 in U. R. Sumaila and A. D. Marsden, editors. 2005 North American Association of Fisheries Economists forum proceedings. Fisheries Centre Research Reports 14(1). Fisheries Centre, University of British Columbia, Vancouver, Canada.

Flannery, W., and M. Ó Cinnéide. 2012. Deriving lessons relating to marine spatial planning from Canada's Eastern Scotian Shelf integrated management initiative. Journal of Environmental Policy and Planning 14(1):97-117. http://dx.doi.org/10.1080/1523908X.2012 .662384

FNFC [First Nations Fisheries Council]. 2012. BC First Nations Fisheries Council: 2012-2015 strategic plan. FNFC, Vancouver, Canada. [online] URL: http://www.fnfisheriescouncil.ca/downloads/ strat-plan.pdf.

Folke, C., L. Pritchard, Jr., F. Berkes, J. Colding, and U. Svedin. 2007. The problem of fit between ecosystems and institutions: ten years later. Ecology and Society 12(1): 30. [online] URL: http:// www.ecologyandsociety.org/vol12/iss 1/art30/.

Gelcich, S., T. P. Hughes, P. Olsson, C. Folke, O. Defeo, M. Fernández, S. Foale, L. H. Gunderson, C. Rodríguez-Sickert, M. Scheffer, R. S. Steneck, and J. C. Castilla. 2010. Navigating transformations in governance of Chilean marine coastal resources. Proceedings of the National Academy of Sciences 107 (39):16794-16799. http://dx.doi.org/10.1073/pnas.1012021107

Green, T. L. 2007. Improving human wellbeing and ecosystem health on BC's coast: the challenge posed by historic resource extraction. Journal of Bioeconomics 9(3):245-263. http://dx.doi. org/10.1007/s10818-007-9024-3

Gutiérrez, N. L., R. Hilborn, and O. Defeo. 2011. Leadership, social capital and incentives promote successful fisheries. Nature 470(7334):386-389. http://dx.doi.org/10.1038/nature09689

Ha-Shilth-Sa. 2014. Nuu-chah-nulth fishing rights upheld by Supreme Court. Ha-Shilth-Sa January 30, 2014. [online] URL: http://www.hashilthsa.com/news/2014-01-30/nuu-chah-nulth-fishingrights-upheld-supreme-court.

Haggan, N., N. Turner, J. Carpenter, J. T. Jones, Q. Mackie, and C. Menzies. 2006. 12,000+ years of change: linking traditional and modern ecosystem science in the Pacific Northwest. University of British Columbia Fisheries Centre, Victoria, Canada. [online] URL: http://www.fisheries.ubc.ca/node/3776.

Hand, C. M., W. Hajas, N. Duprey, J. Lochead, J. Deault, and J. Caldwell. 2008. An evaluation of fishery and research data collected during the phase 1 sea cucumber fishery in British Columbia, 1998 to 2007. Research document 2008/065. Fisheries and Oceans 
Canada, Nanaimo, Canada. [online] URL: http://www.dfo-mpo. gc.ca/csas-sccs/publications/resdocs-docrech/2008/2008 065-eng. $\underline{\text { htm. }}$.

Hanson, A. J. 1998. Sustainable development and the oceans. Ocean and Coastal Management 39(1-2):167-177. http://dx.doi. org/10.1016/S0964-5691(98)00035-0

Hardin, G. 1968. The tragedy of the commons. Science 162 (3859):1243-1248. http://dx.doi.org/10.1126/science.162.3859.1243

Harris, D. C. 2001. Fish, law, and colonialism: the legal capture of salmon in British Columbia. University of Toronto Press, Toronto, Canada.

Harris, D. C., and P. Millerd. 2010. Food fish, commercial fish, and fish to support a moderate livelihood: characterizing Aboriginal and treaty rights to Canadian fisheries. Arctic Review on Law and Politics 1(1):82-107. [online] URL: http://site.uit.no/ arcticreview/files/2012/11/AR2010-1_HarrisMillerd.pdf.

Huntjens, P., L. Lebel, C. Pahl-Wostl, J. Camkin, R. Schulze, and N. Kranz. 2012. Institutional design propositions for the governance of adaptation to climate change in the water sector. Global Environmental Change 22(1):67-81. http://dx.doi. org/10.1016/j.gloenvcha.2011.09.015

Hutchings, J. A., and J. R. Post. 2013. Gutting Canada's Fisheries Act: no fishery, no fish habitat protection. Fisheries 38 (11):497-501. http://dx.doi.org/10.1080/03632415.2013.848345

Jessen, S. 2011. A review of Canada's implementation of the Oceans Act since 1997-from leader to follower? Coastal Management 39(1):20-56. http://dx.doi.org/10.1080/08920753.2011.544537

Johnsen, D. B. 2009. Salmon, science, and reciprocity on the northwest coast. Ecology and Society 14(2): 43. [online] URL: http://www.ecologyandsociety.org/vol14/iss2/art43/.

Johnson, C. 2004. Uncommon ground: the 'poverty of history' in common property discourse. Development and Change 35 (3):407-434. http://dx.doi.org/10.1111/j.1467-7660.2004.00359.x

Jones, R., C. Rigg, and L. Lee. 2010. Haida marine planning: First Nations as a partner in marine conservation. Ecology and Society 15(1): 12. [online] URL: http://www.ecologyandsociety.org/ vol15/iss 1/art12/.

Jones, R., M. Shepert, and N. J. Sterritt. 2004. Our place at the table: First Nations in the B.C. fishery. First Nation Panel on Fisheries, Vancouver, Canada.

Khan, A. 2006. Sustainability challenges in the geoduck clam fishery of British Columbia: policy perspectives. Coastal Management 34:443-453. http://dx.doi.org/10.1080/08920750600860548

Kearney, J., F. Berkes, A. Charles, E. Pinkerton, and M. Wiber. 2007. The role of participatory governance and community-based management in integrated coastal and ocean management in Canada. Coastal Management 35(1):79-104. http://dx.doi. org/10.1080/10.1080/08920750600970511

King, L. 2004. Competing knowledge systems in the management of fish and forests in the Pacific Northwest. International Environmental Agreements 4(2):161-177. http://dx.doi.org/10.1023/ B:INEA.0000040418.31663.61
Lam, W. F. 1999. Governing irrigation systems in Nepal: institutions, infrastructure, and collective action. ICS Press, Oakland, California, USA.

Levin, S. A., and J. Lubchenco. 2008. Resilience, robustness, and marine ecosystem-based management. BioScience 58(1):27-32. http://dx.doi.org/10.1641/B580107

Mahon, R., P. McConney, and R. N. Roy. 2008. Governing fisheries as complex adaptive systems. Marine Policy 32 (1):104-112. http://dx.doi.org/10.1016/j.marpol.2007.04.011

Marshall, N. A., P. A. Marshall, J. Tamelander, D. Obura, D. Malleret-King, and J. E. Cinner. 2010. A framework for social adaptation to climate change. IUCN, Gland, Switzerland. [online] URL: https://portals.iucn.org/library/efiles/documents/2010-022. pdf.

McGinnis, M. D. 2011. An introduction to IAD and the language of the Ostrom workshop: a simple guide to a complex framework. Policy Studies Journal 39(1):163-183. http://dx.doi.org/10.1111/ j.1541-0072.2010.00401.x

McGinnis, M. D., and E. Ostrom. 2014. Social-ecological system framework: initial changes and continuing challenges. Ecology and Society 19(2): 30. http://dx.doi.org/10.5751/ES-06387-190230

Morrow, C. E., and R. W. Hull. 1996. Donor-initiated common pool resource institutions: the case of the Yanesha Forestry Cooperative. World Development 24(10):1641-1657. http://dx.doi. org/10.1016/0305-750X(96)00064-2

Nelson, S. 2011. West coast fishing fleet: analysis of commercial fishing licence, quota, and vessel values. Fisheries and Oceans Canada, Nanaimo, Canada. [online] URL: http://www.dfo-mpo. gc.ca/Library/342459.pdf.

O'Regan, S. M. 2015. Harvesters' perspectives on the management of British Columbia's giant red sea cucumber fishery. Marine Policy 51:103-110. http://dx.doi.org/10.1016/j. marpol.2014.07.025

Ommer, R. E. 2007. Coasts under stress: restructuring and socialecological health. McGill-Queen's Press, Montreal, Canada.

Ostrom, E. 1990. Governing the commons: the evolution of institutions for collective action. Cambridge University Press, Cambridge, UK. http://dx.doi.org/10.1017/CBO9780511807763

Ostrom, E. 1993. Design principles in long-enduring irrigation institutions. Water Resources Research 29(7):1907-1912. http:// dx.doi.org/10.1029/92WR02991

Ostrom, E. 1999. Coping with tragedies of the commons. Annual Review of Political Science 2:493-535. http://dx.doi.org/10.1146/ annurev.polisci.2.1.493

Ostrom, E. 2007. A diagnostic approach for going beyond panaceas. Proceedings of the National Academy of Sciences 104 (39):15181-15187. http://dx.doi.org/10.1073/pnas.0702288104

Ostrom, E. 2009. A general framework for analyzing sustainability of social-ecological systems. Science 325 (5939):419-422. http://dx.doi.org/10.1126/science.1172133 
Ostrom, E. 2010. Analyzing collective action. Agricultural Economics 41(S1):155-166. http://dx.doi.org/10.1111/ j.1574-0862.2010.00497.x

Ostrom, E., and M. Cox. 2010. Moving beyond panaceas: a multitiered diagnostic approach for social-ecological analysis. Environmental Conservation 37(4):451-463. http://dx.doi.org/10.1017/ $\underline{\mathrm{S} 0376892910000834}$

O'Regan, S. M. 2015. Harvesters' perspectives on the management of British Columbia's giant red sea cucumber fishery. Marine Policy 51:103-110. http://dx.doi.org/10.1016/j. marpol.2014.07.025

Perry, R. I., C. J. Walters, and J. A. Boutillier. 1999. A framework for providing scientific advice for the management of new and developing invertebrate fisheries. Reviews in Fish Biology and Fisheries 9(2):125-150. http://dx.doi.org/10.1023/A:1008946522213

Pinkerton, E., and L. John. 2008. Creating local management legitimacy. Marine Policy 32(4):680-691. http://dx.doi.org/10.1016/ j.marpol.2007.12.005

Pinkerton, E., and J. Silver. 2011. Cadastralizing or coordinating the clam commons: Can competing community and government visions of wild and farmed fisheries be reconciled? Marine Policy 35(1):63-72. http://dx.doi.org/10.1016/j.marpol.2010.08.002

Plummer, R. 2009. The adaptive co-management process: an initial synthesis of representative models and influential variables. Ecology and Society 14(2): 24. [online] URL: http://www. ecologyandsociety.org/vol14/iss2/art24/.

Plummer, R., and D. Armitage. 2007. A resilience-based framework for evaluating adaptive co-management: linking ecology, economics and society in a complex world. Ecological Economics 61(1):62-74. http://dx.doi.org/10.1016/j.ecolecon.2006.09.025

Plummer, R., B. Crona, D. R. Armitage, P. Olsson, M. Tengö, and O. Yudina. 2012. Adaptive comanagement: a systematic review and analysis. Ecology and Society 17(3): 11. http://dx.doi. org/10.5751/ES-04952-170311

Poteete, A. R., and E. Ostrom. 2004. Heterogeneity, group size and collective action: the role of institutions in forest management. Development and Change 35(3):435-461. http://dx. doi.org/10.1111/j.1467-7660.2004.00360.x

Price, K., A. Roburn, and A. MacKinnon. 2009. Ecosystem-based management in the Great Bear Rainforest. Forest Ecology and Management 258(4):495-503. http://dx.doi.org/10.1016/j.

foreco.2008.10.010

Rutherford, M., M. Dickinson, and T. Gunton. 2010. An evaluation of the national framework for marine planning in Canada. Environments: A Journal of Interdisciplinary Studies 37 (3):47-69. [online] URL: http://jps.library.utoronto.ca/index.php/ ejis/article/view/15059/12058.

Singleton, S. 2009. Native people and planning for marine protected areas: how "stakeholder" processes fail to address conflicts in complex, real-world environments. Coastal Management 37(5):421-440. http://dx.doi.org/10.1080/08920750902954072
Smith, M., and A. Sterritt. 2007. From conflict to collaboration: the story of the Great Bear Rainforest. Forest Ethics, San Francisco, California, USA. [online] URL: http://sfigreenwash. org/downloads/WWFpaper.pdf.

Trosper, R. L. 2003. Resilience in pre-contact Pacific Northwest social ecological systems. Conservation Ecology 7(3): 6. [online] URL: http://www.consecol.org/vol7/iss3/art6/.

Tschakert, P., and K. A. Dietrich. 2010. Anticipatory learning for climate change adaptation and resilience. Ecology and Society 15 (2): 11. [online] URL: http://www.ecologyandsociety.org/vol15/ iss2/art11/.

Turner, K. L., and C. P. H. Bitonti. 2011. Conservancies in British Columbia, Canada: bringing together protected areas and First Nations' interests. International Indigenous Policy Journal 2(2): 3. [online] URL: http://ir.lib.uwo.ca/iipj/vol2/iss2/3.

Turner, N. J., and F. Berkes. 2006. Coming to understanding: developing conservation through incremental learning in the Pacific Northwest. Human Ecology 34(4):495-513. http://dx.doi. org/10.1007/s10745-006-9042-0

Turner, N. J., R. Gregory, C. Brooks, L. Failing, and T. Satterfield. 2008. From invisibility to transparency: identifying the implications. Ecology and Society 13(2): 7. [online] URL: http:// www.ecologyandsociety.org/vol13/iss2/art7/.

Whaley, L., and E. K. Weatherhead. 2014. An integrated approach to analyzing (adaptive) comanagement using the "politicized" IAD framework. Ecology and Society 19(1): 10 http://dx.doi.org/10.5751/ES-06177-190110

Wiber, M., A. Charles, J. Kearney, and F. Berkes. 2009. Enhancing community empowerment through participatory fisheries research. Marine Policy 33(1):172-179. http://dx.doi.org/10.1016/ j.marpol.2008.05.009

Wiber, M. G., M. A. Rudd, E. Pinkerton, A. T. Charles, and A. Bull. 2010. Coastal management challenges from a community perspective: the problem of 'stealth privatization' in a Canadian fishery. Marine Policy 34(3):598-605. http://dx.doi.org/10.1016/j. marpol.2009.11.010 
Appendix 1. Enablers of and barriers to devolving fisheries management to Coastal First Nations

\begin{tabular}{|c|c|c|}
\hline & Current Problems \& Barriers & Enablers \& Solutions \\
\hline $\begin{array}{l}\text { Legal } \\
\text { environment }\end{array}$ & $\begin{array}{l}\text { - Historical exclusion from decision-making } \\
\text { - Conflicts over monitoring \& enforcement } \\
\text { authority } \\
\text { - Cost of legal action/conflict resolution }\end{array}$ & $\begin{array}{l}\text { - Aboriginal rights \& title recognized } \\
\text { - Documenting historical use \& occupancy } \\
\text { - Affirming pertinent traditional laws and rules (e.g. } \\
\text { Gvi'ilas -- the Heiltsuk Nation's laws of their } \\
\text { ancestors -- are their guiding principles for } \\
\text { resource management) } \\
\text { - New relationships with province, industry } \\
\text { - Just redistribution of commercial harvesting rights } \\
\text { to First Nations }\end{array}$ \\
\hline $\begin{array}{l}\text { Policy } \\
\text { environment }\end{array}$ & $\begin{array}{l}\text { - Dominant top-down paradigm } \\
\text { - Industry interests dominate } \\
\text { - Government silos; disconnect between } \\
\text { political \& operational at DFO } \\
\text { - Limited local participation in decision- } \\
\text { making }\end{array}$ & $\begin{array}{l}\text { - Harmonized Marine Use Plans for CCFN } \\
\text { - New relationships and understandings } \\
\text { - } \quad \text { Reconciliation protocols } \\
\text { - Government-to-government letters of } \\
\text { intent and agreements } \\
\text { Increasing participation in industry and } \\
\text { commercial activities }\end{array}$ \\
\hline $\begin{array}{l}\text { Governance } \\
\text { and } \\
\text { decision- } \\
\text { making } \\
\text { processes }\end{array}$ & $\begin{array}{l}\text { - Insufficient/excessively expensive conflict } \\
\text { resolution mechanisms } \\
\text { - Inappropriate inclusion rules for } \\
\text { "stakeholder" negotiations } \\
\text { - Poor communication across scales } \\
\text { - Decreasing DFO capacity due to staff and } \\
\text { funding cuts }\end{array}$ & $\begin{array}{l}\text { - Increasing local organization \& capacity } \\
\text { - Harmonized Marine Use Plans for CCFN } \\
\text { - New cross-scale, bridging organizations and } \\
\text { processes } \\
\text { - eg. CCIRA, MaPP, CGWN, FNFC } \\
\text { - De facto authority } \\
\text { - E.g. coastal guardian watchmen, Kitasoo } \\
\text { prevented sea cucumber harvest in an } \\
\text { area adjacent to their community }\end{array}$ \\
\hline $\begin{array}{l}\text { Knowledge, } \\
\text { science, and } \\
\text { information }\end{array}$ & $\begin{array}{l}\text { - Insufficient science baseline } \\
\text { - DFO often lacks fine-scale information to } \\
\text { inform local plans } \\
\text { - Local ecological knowledge (LEK) } \\
\text { undervalued by current regime } \\
\text { - Local science capacity not adequately } \\
\text { recognized }\end{array}$ & $\begin{array}{l}\text { - Increasing capacity for science and monitoring } \\
\text { - Increseased integration of LEK into scientific } \\
\text { studies to improve monitoring } \\
\text { - E.g. CCIRA, Coastal Guardian Watchmen Network } \\
\text { collecting baseline data and developing capacity }\end{array}$ \\
\hline Relationships & $\begin{array}{l}\text { - Poor communication between actors } \\
\text { - Insufficient collaborative capacity in } \\
\text { government } \\
\text { - Tense relations between First Nations and } \\
\text { federal government }\end{array}$ & $\begin{array}{l}\text { - Improving relationships between } \\
\text { - } \quad \text { First Nations and industry } \\
\text { - } \quad \text { First Nations and } \mathrm{BC} \text { government } \\
\text { - } \quad \text { First Nations }\end{array}$ \\
\hline $\begin{array}{l}\text { Local } \\
\text { organizing \& } \\
\text { community } \\
\text { capacity }\end{array}$ & $\begin{array}{l}\text { - Colonial legacy of disenfranchisement } \\
\text { - Out-migration } \\
\text { - Few trained locals } \\
\text { - Continuity of leadership/programming } \\
\text { - Cost of travel, distance between } \\
\text { communities }\end{array}$ & $\begin{array}{l}\text { - Strong vision \& harmonized marine plans } \\
\text { - Strengthening ties between nations } \\
\text { - Local/FN resource management offices } \\
\text { - Increasing capacity in science and monitoring (e.g. } \\
\text { CGWN and CCIRA) }\end{array}$ \\
\hline $\begin{array}{l}\text { Capital, } \\
\text { funding, \& } \\
\text { incentives }\end{array}$ & $\begin{array}{l}\text { - Limited access to local resources \& } \\
\text { associated revenue } \\
\text { - } \quad \text { Expensive licenses } \\
\text { - Perception of inequitable } \\
\text { allocation }\end{array}$ & $\begin{array}{l}\text { - Revenue sharing agreements } \\
\text { - Initiatives to increase access to licenses } \\
\text { - Pacific Integrated Commercial Fisheries } \\
\text { Initiative) } \\
\text { - Aboriginal Fisheries Strateg (AFS) } \\
\text { - Support from non-profit funders (e.g. Moore } \\
\text { foundation) } \\
\text { - Diversified economic development opportunities } \\
\text { - Aquaculture } \\
\text { - Processing } \\
\text { - Value-added products }\end{array}$ \\
\hline
\end{tabular}

